8. Балаболкин И.И., Смирнов И.Е., Булгакова В.А. и др. Современная концепция патогенеза бронхиальной астмы у детей. // Иммунология, аллергология, инфектология. 2006. №1. С. 26-35.

9. Ильенкова Н.А. Оптимизация диагностики и лечения болезней органов дыхания у детей: Автореф. дис. д-ра мед. наук. Красноярск, 2007. 46 с.

10. Булгакова В.А., Балаболкин И.И., Сенцова Т.Б., Булгакова В.А., Рылеева И.В. Влияние вирусных инфекций на состояние гуморального и клеточного иммунитета у детей с аллергическими заболеваниями // Иммунология. 2005. №1. С. 21-25.

11.ДемкоИ.В.Клиническиеифармакоэкономические проблемы бронхиальной астмы / И.В. Демко, И.П. Артюхов // Первая краевая. 2008. №33. С. 19-26.

12.Балаболкин И.И., Сюракшина М.В., Тюменцева Е.С. Иммунокорригирующая терапия в комплексном лечении детей с аллергией // Лечащий врач. 2005. №7. С. 40-43.

13. Зайцева О.В. Бронхиальная астма и респираторные инфекции у детей// Медицинский совет. 2013. №1. C. 34-41.

14. Герасимов С.В. Перекисное окисление липидов и антиоксидантная защита при бронхиальной астме / С.В. Герасимов // Укр. мед. часопис. 2000. №1 (15). С. 86-91.

15. Балаболкин И.И. Лечение аллергических болезней у детей. / Под ред. И. И. Балаболкина.-М.:
«Медицинское информационное агенство», 2008.-352с.

16. Любицкий О.Б, Клебанов г.И., Дьяконова В.А. Изучение антиоксидантных свойств иммуномодулятора полиоксидония. //Иммунология. 2005. №4. С. 200-205.

17. Болотских В.И. Клинико-лабораторное обоснование использования дифференцированной иммунокоррекции в комплексном лечении бронхиальной астмы// Автореф. дисс. на соискание докт. мед наук.-2007. 48 c.

18. Шувалова Ю.В. Клинико-лабораторная эффективность полиоксидония в комплексной терапии синдрома рецидивирующей бронхиальной обструкции у детей / Ю. В. Шувалова, Т.Б. Ахвердиева, Н.Г. Герасимова, Е.Н. Коваленко, Т.Е. Чашина, Л.В. Зотова, В.А. Горбатов // Современные проблемы науки и образования. 2013. №2. www.science-education.ru/ 108-8968.

19. Захарова Л.И., Битоцкая Т.М., Мокина Н.А. Эффективность рибосомального иммунокорректора в профилактике обострений рецидивирующего обструктивного бронхита и бронхиальной астмы у детей// Вопросы современной педиатрии. Т. 4 . №5. 2005. С. 66-68.

20. Шальнева Т.В. Эффективность использования дерината в комплексной фармакотерапии рецидивирующего бронхита и пневмоний у детей// Автореф. дисс. на соискание канд. мед наук. 2009. 22 с.

(C) 2015

\title{
THE MEANING OF PEROXIDATION AND ANTIOXIDANT SYSTEMS IN THE PATHOGENESIS OF BRONCHIAL OBSTRUCTION
}

N.G. Gerasimova, doctor of medicine, professor of the pediatrics department Mordovia N.P. Ogarev State University, Saransk (Russia)

T.B. Akhverdieva, post-graduate student of the pediatrics department Mordovia N.P. Ogarev State University, Saransk (Russia)

Y.V. Shuvalova, post-graduate student of the pediatrics department Mordovia N.P. Ogarev State University, Saransk (Russia)

E.N. Kovalenko, candidate of biological sciences, associate professor of the normal physiology department with a course of medical biochemistry Mordovia N.P. Ogarev State University, Saransk (Russia)

V.A. Gorbatov, candidate of medical sciences, senior lecturer of the pediatrics department Mordovia N.P. Ogarev State University, Saransk (Russia)

\begin{abstract}
Annotation. the pathogenesis of several diseases of respiratory system, in particular recurrent obstructive bronchitis and bronchial asthma are founded on syndrome of bronchial obstruction. The study of the pathogenesis aspects of these diseases is essential to improve the efficiency of treatment and rehabilitation of patients. Patients with bronchial obstruction syndrome have imbalance between reactions of lipid peroxidation and antioxidant system with a significant damage to biological membranes at the cellular and subcellular level. Metabolic response in these patients have lower compensatory capacity, that leads to development of more severe forms of the disease. The analysis of the data obtained showed that prior to initiating therapy in children with recurrent obstructive syndrome was a decrease in antioxidant protection indicators (ceruloplasmin content and catalase activity in blood serum) and an increase in indicators of intoxication (malondialdehyde content in the blood serum). After the use of polyoxidonium in a complex therapy the patients showed a reliable increase in the content of ceruloplasmin and catalaza activity in the blood serum and decrease in the content of malondialdehyde in the blood serum. It was found that before treatment patients had an increase in the index of intoxication (nitric oxide), after the use of polyoxidonium in a complex therapy they had a significant reduction of nitric oxide in the blood serum.

Keywords: bronchial obstruction; bronchial asthma; recurrent bronchitis; lipid peroxidation; antioxidant protection; patients; therapy; biochemical parameters.
\end{abstract}

\section{УДК 504.054 \\ ОЦЕНКА КАЧЕСТВА ТЕРРИТОРИИ, ПРИЛЕГАЮЩЕЙ К ОАО «ЗАВОД БУРОВОГО ОБОРУДОВАНИЯ»}

(C) 2015

М.Ю. Гарицкая, кандидат биологических наук, доцент кафедры экологии и природопользования Оренбургский государственный университет, Оренбург (Россия)

А.И. Байтелова, кандидат технических наук, доцент кафедры экологии и природопользования Оренбургский государственный университет, Оренбург (Россия) Л.А. Пикус, студентка кафедры экологии и природопользования Оренбургский государственный университет, Оренбург (Россия)

К.А. Косачёва, студентка кафедры экологии и природопользования Оренбургский государственньй университет, Оренбург (Россия)

Аннотация. Почва, выполняя ряд важных функций, является геомембраной и влияет на протекание большинства процессов в биосфере. При этом геохимические процессы, происходящие в почвах, играют важную роль в судьбе загрязнителей, так как органическое вещество, контролируя их перераспределение в экосистеме 
между ее различными компонентами, как правило, приводит к формированию устойчивых зон загрязнения. Почва не только геохимически аккумулирует компоненты загрязнений, но и выступает как природный буфер, контролирующий перенос химических элементов и соединений в атмосферу. Вокруг промышленных предприятий образуются геохимические аномалии с повышенным содержанием загрязняющих веществ, радиус которых может достигать 10-50 км, а влияние крупных промышленных центров прослеживается на расстоянии до 100 км. Все известные технологические процессы обработки металлов сопровождаются образованием больших количеств отходов, которые загрязняют атмосферу, воду и поверхность земли. Машиностроение является важной отраслью промышленности Оренбургской области и представлено предприятиями оборонно-промышленного комплекса, сельхозмашиностроения, станкостроения, производством оборудования для черной и цветной металлургии, транспортных средств, электродвигателей, бытовой техники.

В машиностроительный комплекс Оренбургской области входит более 70 крупных предприятий. Доля продукции машиностроения в объеме промышленного производства составляет порядка 8\%. При этом природная среда города Оренбурга слабозащищена от большинства неблагоприятных геоэкологических факторов. На основании этого, нами было проведено исследование качества почв и экологической ситуации, складывающейся на территории г. Оренбурга, находящейся в зоне влияния предприятия ОАО «Завод бурового оборудования».

Ключевые слова: экологическая ситуация; источники загрязнения; показатель химического загрязнения; коэффициент концентрации.

Почва, выполняя ряд важнейших планетарных и экологических функций (поддержание жизни на Земле, взаимодействие большого и малого круговоротов веществ, регулирование состава атмосферы и гидросферы, и др.), является геомембраной, влияющей на протекание большинства процессов в биосфере. При этом особенность почвы-это медленное накопление изменений (высокая буферность) и еще более медленное восстановление утраченных функций [1]. Геохимические процессы, происходящие в почвах, играют важную роль в судьбе поллютантов, поскольку органическое вещество, контролируя их перераспределение в экосистеме между еe различными компонентами, как правило, приводит к формированию устойчивых зон загрязнения. С этой точки зрения большое значение имеет изучение показателей химического загрязнения, биотоксичности почвы, а также установление форм миграции поллютантов под воздействием факторов окружающей среды [2]. Почва, в отличие от других компонентов природной среды, не только геохимически аккумулирует компоненты загрязнений, но и выступает как природный буфер, контролирующий перенос химических элементов и соединений в атмосферу, гидросферу и живое вещество.

Известно, что вокруг промышленных предприятий образуются геохимические аномалии с повышенным содержанием загрязняющих веществ, радиус которых может достигать 10-50 км, а влияние крупных промышленных центров прослеживается на расстоянии до 100 км.

Все известные технологические процессы обработки металлов сопровождаются образованием больших количеств отходов в виде вредных газов и пыли, шлаков, шламов, сточных вод, содержащих различные химические компоненты, окалины, боя огнеупоров, мусора и других выбросов, которые загрязняют атмосферу, воду и поверхность земли. Попадая на поверхность почв, загрязняющие вещества могут либо накапливаться, либо рассеиваться в зависимости от характера геохимических барьеров, свойственных данной территории [5].

Машиностроение является важной отраслью промышленности Оренбургской области и представлено предприятиями оборонно-промышленного комплекса, сельхозмашиностроения, станкостроения, производством оборудования для черной и цветной металлургии транспортных средств, электродвигателей, бытовой техники.

В машиностроительный комплекс Оренбургской области входит более 70 крупных предприятий. Доля продукции машиностроения в объеме промышленного производства составляет порядка 8\%. Проводимая промышленная политика области направлена на выпуск предприятиями машиностроения готовой, конкурентоспособной продукции [4]. При этом стоит отметить слабую защищенность природной среды города Оренбурга от большинства неблагоприятных геоэкологических факторов. На значительных площадях поверхность города подвергается экзогенным процессам (речная эрозия, плоскостной смыв, оврагообразование, оползни и др.). На большей части площади Оренбурга отсутствует экранирующий слой над подземными водами. Грунтовые воды относятся к категории либо условно защищённых, либо вообще незащищённых. В результате $85 \%$ территории города относится к категории с весьма неблагоприятными геоэкологическими условиями.

Объектом исследования являлась территория, прилегающая к предприятию ОАО «Завод бурового оборудования», расположенный в г. Оренбурге.

На территории города имеется множество источников загрязнения окружающей среды и отделить их территориально друг от друга подчас невозможно, поэтому целью исследования являлось оценить экологическую ситуацию, складывающуюся на данной территории. Предприятие ОАО «Завод бурового оборудования» расположено на одной промышленной площадке. Ближайший жилой массив расположен в 6 м.

Основным видом деятельности ОАО «Завод бурового оборудования» является производство бурового оборудования:

1. Буровой инструмент: трубы бурильные, технологические и бурильные трубы для КРС, штанги с системой телеметрии, штанги бурильные шнековые, штанги бурильные для ГНБ, обсадные колонковые трубы, вилки, переходники, наголовники, замки.

2. Комплекс ССК, Wireline N, Wireline H, Wireline P.

3. Буровые установки.

4. Буровые колонки, алмазные коронки.

5. Буровые растворы.

6. Комплектующие к буровым установкам.

На территории промплощадки расположены: котельная, производственный цех, инструментальный участок, гараж, участок нестандартной продукции.

Источниками организованных выбросов на предприятии являются труба от водонагревательного котла и вентиляционные трубы от котла заточного станка, сварочных аппаратов, окрасочно-сушильной камеры, соляной ванны, печи закалочной, печь отпускной, печи цементации. Основными загрязняющими веществами, выбрасываемыми данными источниками являются: диоксид азота, оксид азота и оксид углерода.

Приоритетным направлением ветра является северовосточное направление. В связи с этим нами были отобраны пробы почвы на границе санитарно- защитной зоны- 50 м на северо-востоке и юго-западе, далее на расстоянии 500 м и 1000 м от С33 также на северо-востоке и юго-западе. Все образцы были отобраны и подготовлены согласно стандартным методикам и по ГОСТ 26488 85, ПНДФ 16.1:2:2.2:3.51-08, МУ М. 1993г.

В отобранных пробах определялось содержание кислотообразующих веществ, металлов и рН. Результаты исследований представлены в таблице 1. 

относится к зоне с относительно удовлетворительной экологической ситуацией.

По показателю химического загрязнения почв тер-

\begin{tabular}{|c|c|c|c|c|c|c|c|c|c|c|c|c|}
\hline \multirow{2}{*}{$\begin{array}{l}\text { Мecto } 0 \\
\text { or6opa }\end{array}$} & \multicolumn{11}{|c|}{ Концентрация загрязняющих веществ, мг/кг } & \multirow[t]{2}{*}{$\mathrm{pH}$} \\
\hline & $\mathrm{NO}_{3}$ & $\mathrm{NO}_{2}$ & $\mathrm{HCO}_{3}$ & $\mathrm{Cl}$ & HS & $\mathrm{Ca}$ & $\mathrm{Mg}$ & $\mathrm{Zn}$ & $\mathrm{Fe}$ & $\mathrm{NH}_{4}$ & $\mathrm{SO}_{4}$ & \\
\hline Ю03-50 & 64,3 & 0,21 & 435,8 & 328,3 & 10,9 & 75,4 & 18,1 & 0,15 & 21,9 & 93,15 & 11,03 & 5,4 \\
\hline $\begin{array}{l}\text { Ю3- } \\
500\end{array}$ & 34,7 & 0,14 & 290,4 & 112,7 & 6,4 & 127,4 & 26,4 & 0,13 & 1,65 & 78,4 & 7,4 & 5,2 \\
\hline $\begin{array}{l}\text { Ю3- } \\
1000\end{array}$ & 55,0 & 0,43 & 472,1 & 469,1 & 7,9 & 1429 & 55,3 & 0,11 & 6,56 & 67,32 & 5,85 & 8,4 \\
\hline CB- 50 & 55,4 & 0,54 & 299,8 & 171,9 & 6,13 & 105,1 & 7,9 & 0,11 & 3,5 & 127,5 & 4,4 & 7,3 \\
\hline CB-500 & 138,0 & 0,73 & 355,7 & 115,4 & 3,54 & 1032 & 10 & 0,13 & 6,5 & 56,7 & 5,3 & 8,1 \\
\hline $\begin{array}{l}\text { CB- } \\
1000\end{array}$ & 57,5 & 0,32 & 423,8 & 187,3 & 9,1 & 1219 & 10,75 & 0,11 & 5 & 68,4 & 5,3 & 8,8 \\
\hline
\end{tabular}

Исходя из полученных данных, можно сделать вывод о том, что среди кислотообразующих веществ во всех пробах и на всех расстояниях приоритетным загрязняющим веществом являются гидрокарбонат-и хлорид-ионы, концентрация которых изменяется от 290,4 до 472,1 мг/кг., и от 112,7 до 469,1 мг/кг соответственно. Среди металлов в почве преобладают ионы кальция, концентрация которого изменяется от 75,4 до 142,9 мг/л. Анализ pH почв показал, что значение рН в почвах юго-западного направления изменяется с увеличением расстояния от 5,4 до 8,4, т.е. pH смещается от кислой до щелочной среды. В почвах северо-восточного направления складывается более благоприятная ситуация по значениям pH, т.к. оно составляет 7,3- 8,8 и имеет щелочную среду. Для выявления зон экологического неблагополучия нами рассчитывался коэффициент концентрации (К) и показатель химического загрязнения $\left(\mathrm{X}_{\mathrm{n}}\right)$ почв, которые определяли по формуле:

$$
X_{n}=K_{1}+K_{2}+\ldots+K_{n}=\sum^{n} K_{i},(1)
$$

где Кі-коэффициент концентрации і-го загрязняющего вещества.

$$
K_{i}=C_{i} / C_{0},(2)
$$

где Сi-концентрация і-го загрязняющего компонента, мг/кг:

$\mathrm{C}_{0}$-фоновая концентрация і-го компонента, мг/ кг [3].

Расчеты коэффициента концентрации и показателя химического загрязнения осуществлялись относительно значений фоновых концентраций, отобранных в Ташлинском районе Оренбургской области. В ходе расчетов были получены следующие результаты, представленные в таблице 2 .

Таблииа 2

Коэффициент концентрачии загрязняютих и пока-

\begin{tabular}{|c|c|c|c|c|c|c|c|c|c|c|c|c|}
\hline \multirow{2}{*}{$\begin{array}{l}\text { Мecto } \\
\text { отбора }\end{array}$} & \multicolumn{11}{|c|}{ Концентрация загрязняющих веществ, мг/кг } & \multirow[b]{2}{*}{ ПX3 } \\
\hline & $\mathrm{NO}_{3}$ & $\mathrm{NO}_{2}$ & $\mathrm{HCO}_{3}$ & $\mathrm{Cl}$ & HS & $\mathrm{Ca}$ & $\mathrm{Mg}$ & Zn & $\mathrm{Fe}$ & $\mathrm{NH}_{4}$ & $\mathrm{SO}_{4}$ & \\
\hline $103-50$ & 6,34 & 0,094 & 1,15 & 11,6 & 2,5 & 0,75 & 0,65 & 15 & 0,97 & 1,22 & 0,57 & 40,83 \\
\hline $103-500$ & 2,51 & 0,071 & 0,76 & 3,98 & 1,45 & 1,25 & 0,94 & 12,4 & 0,07 & 0,95 & 0,45 & 24,83 \\
\hline $103-1000$ & 3,66 & 0,053 & 1,25 & 16,6 & 1,79 & 1,43 & 1,97 & 10 & 0,31 & 0,88 & 0,3 & 38,21 \\
\hline CB-50 & 1,4 & 0,091 & 0,94 & 4,07 & 1,43 & 1,03 & 0,36 & 14,5 & 0,54 & 1,67 & 0,23 & 26,26 \\
\hline CB-500 & 9,2 & 0,092 & 0,79 & 6,06 & 0,8 & 1,04 & 0,28 & 12,4 & 0,35 & 0,74 & 0,27 & 32,02 \\
\hline CB-1000 & 3,83 & 0,039 & 1,1 & 6,6 & 2,07 & $\frac{1,11}{1.21}$ & 0,38 & 9,1 & 0,22 & 0,64 & 0,24 & 25,42 \\
\hline
\end{tabular}
затель химического загрязнения почв

Исходя из данных, приведенных в таблице, можно сделать вывод о том, что по коэффициенту концентрации приоритетными среди кислотообразующих загрязняющих веществ во всех пробах являются хлориды и нитраты, превышения фона по которым составляет от 3,98 до 16,6 раз и от 1,4 до 9,2 раз соответственно. Среди металлов приоритетным во всех пробах и на всех расстояниях от С33 является цинк.

Ранжирование исследуемой территории проводили согласно критериям, разработанным в 1992 году Министерством природы РФ.

Ранжирование проведенное по значениям $\mathrm{pH}$ показало, что данная территория на расстоянии 50 и 500 м в юго-западном направлении относится к зоне экологического бедствия, т.к. $\mathrm{pH}$ среды составляет 5,4 и 5,2 соот- риторию, прилегающую к ОАО «Завод бурового оборудования », на расстояниях 50 и 1000 м от источника в юго-западном направлении и 500 м в северо-восточном направлении следует отнести к зоне с чрезвычайной экологической ситуацией, т.к. ПХ3 изменяется от 32,02 до 40,83, а территория на расстояниях 500 м в юго-западном направлении, 50 м и 1000 м в северо-восточном направлении относится к зоне с критической экологической ситуацией, т.к. ПХЗ изменяется от 24,83 до 26,26.

Таким образом, можно сделать вывод о том, что существенное влияние на распределение примесей оказывают интенсивность и направление ветра. Снос загрязняющих веществ осуществляется в юго-западном направлении, так как приоритетными являются северовосточные ветра, что и подтверждает сложившаяся экологическая обстановка.

\section{СПИСОК ЛИТЕРАТУРЫ}

1. Экологическое почвоведение: Лабораторные занятия для студентов-экологов (бакалавров): Метод. указания / Сост. И.Н. Волкова, г.В. Кондакова; Яросл. гос. ун- т. Ярославль, 2002. 35 с.

2. Экологическая геохимия: Тяжелые металлы в почвах в зоне влияния промышленного города: учебн. пособие/ В.А. Бычинский . Н.В. Вышукевич. Иркутс: Издво Иркут. гос. ун-та 2008. 189 с.

3. Методика «Критерии оценки экологической обстановки территорий для выявления зон чрезвычайной экологической ситуации и зон экологического бедствия» (утв. Минприроды РФ 30.11.1992)// КонсультантПлюс: справочная правовая система 1992-2015.-Режим доступа: http://www.consultant.ru/document/cons_doc LAW 90799/.

4. Портал Правительства Оренбургской области-Режим доступа http://www.orenburg-gov.ru/magnoliaPublic/ regportal/Info/Economics/Industry/cars.html

5. Вальков В.Ф., Казеев К.Ш., Колесников С.И. Экология почв: Учебное пособие для студентов вузов. Часть 3. Загрязнение почв. Ростов-на-Дону: УПЛ РГУ, 2004. 54 с. Соавторы: гл. 1-А.А. Попович, гл. 3-Т.В. Денисова, гл. 7-С.С. Тащиев.

6. Байтелова А.И., Куксанов В.Ф., Тарасова Т.Ф., Гарицкая М.Ю., Грошев И.В. Межгосударственный приграничный экологический мониторинг Оренбургской области (монография) Охрана окружающей среды Оренбургской области. Оренбург: ОГУ, 2006.

7. Байтелова А.И., Тарасова Т.Ф., Гарицкая М.Ю. Оценка экотоксикологического состояния почв территории Илекского района (статья) Вестник Оренбургского государственного университета (75), 2007. Оренбург: ГОУ ОГУ. С. 344-346

8. Байтелова А.И., Тарасова Т.Ф., Гарицкая М.Ю., Тарасова Н.С. Трансграничный перенос загрязняющих веществ и его влияние на состояние природных экосистем приграничных территорий (статья) Вестник Оренбургского государственного университета. Спецвыпуск. Материалы IV Всероссийск. научн.-практ. конф. «Проблемы экологии Южного Урала». Часть II. Пространст.временные особенности структурно-функц. организации и проблемы развития территорий. 2009. Оренбург: ГОУОГУ. С. 373-375.

9. Байтелова А.И., Тарасова Т.Ф. Анализ взаимодействия между техногенной и квазиприродной средами в городской экосистеме (статья) Вестник Оренбургского государственного университета. Спецвыпуск. Материалы IV Bcepocc. научн.-практ. конф. «Проблемы экологии Южного Урала». Часть II. Пространст.-временные особенности структурно-функц. организации и проблемы развития территорий. 2009. Оренбург: ГОУ ОГУ. С.226-228. 
10. Гарицкая М.Ю. Экология города: методические указания для студентов, обучающихся по программам высшего профессионального образования по направлениям подготовки 280700.62 Техносферная безопасность и 022000.62 Экология и природопользование / М.Ю. Гарицкая, А.И. Байтелова, О.В. Чекмарева; М-во образования и науки Рос. Федерации, Федер. гос. бюджет. образоват. учреждение высш. проф. образования «Оренбург. гос. ун-т», Каф. экологии и природопользования.-Электрон. текстовые дан. (1 файл: 419.78 Kb).-Оренбург: ОГУ, 2014

11. Экология региона: учеб. пособие / В.Ф. Куксанов [и др.]; М-во образования и науки Рос. Федерации, Федер. агентство по образованию, Гос. образоват. учреждение высш. проф. образования «Оренбург. гос. ун- т».Оренбург: ГОУ ОГУ, 2008.

12. Соколов М.С. Здоровая почва как необходимое условия жизни человека / М.С. Соколов, Ю.Л. Дородных, А.И. Марченко // Почвоведение, 2010. №7. С. 858- 866.

13. Воробьева Л.А. Щелочные засоленные почвы России / Л.А. Воробьева, Е.И. Панкова // Почвоведение, 2008. №5. С. 517-532. Библиогр.: С. 531-532 (47 назв. ).

14. Керженцев А.С. Почва-основа существования человека / А.С. Керженцев, Ю.А. Кузьменчук // Экология и жизнь, 2009. №4. С. 11-16.-Окончание следует.- Библиогр. в сносках.
15. Керженцев А.С. Почва-основа существования человека / А.С. Керженцев, Ю.А. Кузьменчук // Экология и жизнь, 2009. №5. С. 13-15.-Окончание. Начало в №4.

16. Шибаева, И. Н. Экологический риск и загрязнение почв / И. Н. Шибаева, В. Д. Васильевская // География и природные ресурсы, 2003. №1. С. 28-34.-Ил.: 2 рис.; 1 табл.- Библиогр.: с. 34 (25 назв. ).

17. Кузнецов М.Н. Накопление тяжелых металлов в плодах и почве в зонах техногенного загрязнения / М.Н. Кузнецов, С.М. Мотылева // Вестник Российской академии сельскохозяйственных наук, 2008. №4. С. 80-82.-Библиогр.: с. 82.

18. Груздев В.С. Геохимическая трансформация городских почв в регионах с черной металлургией / В.С. Груздев, Л.П. Груздева // Землеустройство, кадастр и мониторинг земель, 2013. №11. С. 61-65.

19. Карпухин М.М. Влияние компонентов почвы на поглощение тяжелых металлов в условиях техногенного загрязнения / М.М. Карпухин, Д.В. Ладонин // 0032-180X, ISSN Почвоведение, 2008. №11. C.1388- 1398.-Библиогр.: с. 1398 (18 назв. ).

20. Коваль М.А. Загрязнение почв городов, сельскохозяйственных земель и техногенных ландшафтов Оренбургской области [Текст] / Коваль М. А. // Вестник Оренбургского государственного университета. 2006.№4. Прил.-С. 54-56.-Библиогр.: с. 56 (5 назв.). (C) 2015

\section{QUALITY ASSESSMENT TERRITORY ADJACENT TO THE «DRILLING EQUIPMENT PLANT»}

M.Y. Garitskaya, candidate of biological sciences, Associate Professor, Department of Ecology and Environmental Sciences

Orenburg State University, Orenburg (Russia)

A.I. Baitelova, candidate of technical sciences, Associate Professor, Department of Ecology and Environmental Sciences

Orenburg State University, Orenburg (Russia)

L.A. Pikus, a student at the Department of Ecology and Environmental Sciences

Orenburg State University, Orenburg (Russia)

K.A. Kosacheva, a student at the Department of Ecology and Environmental Sciences Orenburg State University, Orenburg (Russia)

Abstract. Soil, performing a number of important functions is the geomembrane and affects the flow of most processes in the biosphere. Wherein geochemical processes occurring in the soil play an important role in the fate of contaminants as organic matter while controlling their redistribution in the ecosystem between its various components are generally leads to the formation of stable areas of contamination. The soil not only geochemically components accumulates contaminants, but also acts as a natural buffer that controls the transfer of chemical elements and compounds in the atmosphere. Around industrial enterprises formed geochemical anomalies with high content of pollutants, which can reach a radius of 10-50 km, and the impact of large industrial centers can be traced to a distance of $100 \mathrm{~km}$. All known processes of metal accompanied by the formation of large amounts of waste that pollutes air, water and land surface. Mechanical engineering is an important industry of the Orenburg region and is represented by enterprises of the military-industrial complex, agricultural machinery, machine tools, equipment for ferrous and non-ferrous metals, vehicles, electric household appliances.

In the machine-building complex of the Orenburg region includes more than 70 large enterprises. The share of engineering products in the volume of industrial production is about $8 \%$. In this case, the natural environment of the city of Orenburg slabozaschischena from most adverse geo-environmental factors. Based on this, we carried out a study on the quality of soil and environmental situation prevailing in the city of Orenburg, in the zone of influence of the enterprise «Plant drilling equipment.»

Keywords: environmental situation; sources of pollution; the rate of chemical contamination; the concentration factor.

УДК 581.9: 502.1

\section{ДОПОЛНЕНИЕ К СПИСКУ ВИДОВ РАСТЕНИЙ САРАТОВСКОЙ ОБЛАСТИ,} НУЖДАЮЩИХСЯ В ОХРАНЕ

(C) 2015

О.Н. Давиденко, кандидат биологических наук, доцент, доцент кафедры ботаники и экологии Саратовский государственный университет, Саратов (Россия)

С.А. Невский, кандидат биологических наук, доцент, доцент кафедры ботаники и экологии Саратовский государственньй университет, Саратов (Россия)

Аннотация. В данной статье приводятся новые сведения о распространении на территории Саратовской области десяти видов растений, рекомендованных для включения в третье издание региональной Красной книги по итогам изучения растительного покрова региона за последние годы. По каждому виду приведены сведения о его местообитании и состоянии ценопопуляций. Исследования выполнены по стандартным методикам, принятым в фитоценологии и гидроботанике. Полученные данные расширяют представление о распространении 